\title{
Life beyond cleavage: the case of Ago2 and hematopoiesis
}

\author{
Javier Martinez ${ }^{1}$ and Meinrad Busslinger ${ }^{2,3}$ \\ ${ }^{1}$ Institute of Molecular Biotechnology of the Austrian Academy of Sciences (IMBA), A-1030 Vienna, Austria; ${ }^{2}$ Research \\ Institute of Molecular Pathology, Vienna Biocenter, A-1030 Vienna, Austria
}

A recent article in The Economist (June 16, 2007) describes research on RNA as the 21st century's Big Bang in biology. The "stars" of the RNA universe are small regulatory RNAs known as microRNAs (miRNAs). These 22 -nt-long RNAs were discovered in 1993 (Lee et al. 1993; Wightman et al. 1993), but their role in biology remained obscure until 2001, when the Tuschl, Ambros, and Bartel laboratories identified hundreds of miRNAs in different organisms (Lagos-Quintana et al. 2001; Lau et al. 2001; Lee and Ambros 2001). Functional analyses of these miRNAs and their associated complexes subsequently led to the discovery of RNA-guided genesilencing pathways as important novel principles in controlling gene expression. miRNAs indeed regulate the expression of a large proportion of eukaryotic protein-coding genes at the post-transcriptional level by sequence-specific binding to the 3' untranslated region $\left(3^{\prime}\right.$ UTR) of mRNAs (Lim et al. 2005). To date, RNA silencing is known to play an important role in diverse biological phenomena such as development, stem cell maintenance, cell proliferation, survival, differentiation, metabolism, and cancer (Kloosterman and Plasterk 2006).

The primary transcripts of miRNA genes are mainly processed by the nuclear RNase III enzyme Drosha into stem-loop-structured miRNA precursors (pre-miRNAs) (Lee et al. 2003; Ruby et al. 2007), which are transported via the Exportin-5 receptor to the cytoplasm (Yi et al. 2003). The cytoplasmic RNase III enzyme Dicer cleaves the pre-miRNAs into double-stranded (ds) RNAs of $\sim 22$ nt (Bernstein et al. 2001; Hutvágner et al. 2001). One strand of these dsRNA intermediates associates as a mature miRNA with a member of the Argonaute protein family to generate an active ribonucleoprotein complex known as RNA-Induced Silencing Complex (RISC). Within this effector complex, both the miRNA and the Argonaute protein fulfill specific roles. The singlestranded miRNA recognizes the target mRNA with full or partial base-pair complementarity. The Argonaute protein helps the miRNA in searching for its target

${ }^{3}$ Corresponding author.

E-MAIL busslinger@imp.ac.at; FAX (43/1) 79730-223150.

Article is online at http://www.genesdev.org/cgi/doi/10.1101/gad.1591407.
mRNA and, upon recognition, can either cleave it or remain tethered to the mRNA to repress its translation and/or regulate its stability. While the biochemistry of the miRNA-guided cleavage reactions is well understood (Martinez and Tuschl 2004; Schwarz et al. 2004), it is still controversial to what extent RISC interferes with the initiation or elongation of translation or controls mRNA stability by sequestration into cytoplasmic processing bodies (P-bodies) (Kiriakidou et al. 2007; Peters and Meister 2007; Pillai et al. 2007).

The Argonaute (Ago) proteins can be subdivided into Ago-like and Piwi-like subfamilies. The mammalian Piwi-like proteins are specifically expressed during spermatogenesis, where they bind a novel set of small RNAs termed Piwi-interacting RNAs (piRNAs) (Aravin et al. 2006; Seto et al. 2007). In contrast, the Ago proteins are broadly expressed in somatic cells, associate with miRNAs and are key actors in different RNA silencing pathways (Peters and Meister 2007; Tolia and Joshua-Tor 2007). The Ago gene family consists of four (AGO1AGO4) and five (Ago1-Ago5) members in human and mouse, respectively (Peters and Meister 2007). However, only the Ago2 protein displays endonucleolytic or "Slicer" activity and can therefore execute miRNA-directed cleavage of target mRNA, provided that the basepairing between the Ago2-associated miRNA and the mRNA sequence is perfect (Liu et al. 2004; Meister et al. 2004). In case of partial complementarity, the Ago 2 protein fails to cleave, but instead interferes with translation of the target mRNA via its translational repression activity. In addition to Ago2, other mammalian Ago proteins are also part of miRNA effector complexes that mediate translational inhibition of target mRNAs (Liu et al. 2004; Meister et al. 2004). Gene disruption in the mouse demonstrated that the Ago2 protein is essential for embryonic development (Liu et al. 2004). To study the function of Ago2 in adult hematopoiesis, O'Carroll et al. (2007) have used conditional gene inactivation to bypass the embryonic lethality and report in this issue of Genes \& Development that Ago2 is a key regulator of B-lymphoid and erythroid development. Retroviral rescue experiments surprisingly revealed that the Slicer endonuclease activity, which is a unique and defining feature of Ago2, is dispensable for hematopoietic develop- 
ment as well as for miRNA biogenesis. Here we discuss these novel data in the context of what is known about the function of miRNAs in hematopoiesis.

\section{MicroRNAs in hematopoietic development}

The function of miRNAs has been studied either by gain- and loss-of-function analyses of individual miRNAs or more globally by preventing the biogenesis of all miRNAs (Table 1). The latter approach relies on the inactivation of Dicer (Dcr), the key enzyme, which is required for the processing of pre-miRNAs into mature miRNAs (Hutvágner et al. 2001). As Dicer is essential for mouse embryogenesis (Bernstein et al. 2003; Yang et al. $2005)$, its in vivo role in adult hematopoiesis can only be studied by conditional mutagenesis. This strategy has so far been applied to $\mathrm{T}$ cell development (Table 1), which proceeds in the thymus from the $\mathrm{CD} 4^{-} \mathrm{CD} 8^{-}$doublenegative (DN) progenitors via $\mathrm{CD}^{+}{ }^{+} \mathrm{CD} 8^{+}$double-positive (DP) thymocytes to $\mathrm{CD} 4^{+} \mathrm{CD} 8^{-}$and $\mathrm{CD}^{-} \mathrm{CD} 8^{+}$ single-positive (SP) $\mathrm{T}$ cells that migrate to, and further mature in, peripheral lymphoid organs. The early-acting Lck-cre transgene initiates Cre-mediated excision of the floxed (fl) Dcr allele in DN cells, thus resulting in complete deletion during the transition to DP thymocytes. As a consequence, the cellularity of the thymus is 10fold decreased in Lck-cre Dcr ${ }^{f l / f l}$ mice, which indicates an essential role for Dicer and, by inference, for miRNAs in the generation and survival of normal numbers of DP thymocytes (Cobb et al. 2005). Dicer appears, however, to be dispensable for CD4 and CD8 lineage commitment and the implementation of their lineage-specific gene expression programs (Cobb et al. 2005). Although the lateracting Cd4-cre transgene inactivates Dcr in DP thymocytes, mature miRNAs are significantly depleted only in peripheral $\mathrm{T}$ cells of Cd4-cre $D c r^{f l / f l}$ mice, resulting in a moderate two- to fourfold decrease of splenic $\mathrm{T}$ cells
(Muljo et al. 2005). Dicer-generated miRNAs are therefore required for optimal maturation and homeostasis of peripheral $\mathrm{T}$ lymphocytes. $\mathrm{CD}^{+} \mathrm{T}$ cells are able to differentiate into four different helper $\mathrm{T}$ cell subtypes, i.e., into $\mathrm{T}_{\mathrm{H}} 1, \mathrm{~T}_{\mathrm{H}} 2, \mathrm{~T}_{\mathrm{H}} 17$, and regulatory $\mathrm{T}\left(\mathrm{T}_{\text {reg }}\right)$ cells. Dicer deficiency is compatible with $\mathrm{T}_{\mathrm{H}} 1$ and $\mathrm{T}_{\mathrm{H}} 2$ cell differentiation (Muljo et al. 2005). However, the absence of Dicer compromises naïve $\mathrm{CD}^{+}$and $\mathrm{T}_{\mathrm{H}^{2}} 2$ cells in their ability to repress the $\mathrm{T}_{\mathrm{H}} 1$-specific cytokine IFN $\gamma$, suggesting a role for miRNAs in the repression of the $T_{H} 1$ gene expression program (Muljo et al. 2005). Like all $\mathrm{T}$ cells, $\mathrm{T}_{\text {reg }}$ cells also originate in the thymus, but then patrol peripheral organs to prevent autoimmunity by suppressing autoreactive $\mathrm{T}$ cells (Zheng and Rudensky 2007). Early Dcr inactivation in Lck-cre $D c r^{f l / f 1}$ mice interferes with the development of $\mathrm{T}_{\text {reg }}$ cells in the thymus, whereas later deletion in Cd4-cre $D c r^{f l / f 1}$ mice results in approximately threefold lower numbers of peripheral $\mathrm{T}_{\text {reg }}$ cells in the spleen (Cobb et al. 2006). This moderate decrease in peripheral $\mathrm{T}_{\text {reg }}$ cells is, however, sufficient to lead to a late onset of autoimmune disease in Cd4-cre Dcr ${ }^{f l / f l}$ mice (Cobb et al. 2006). It is, however, surprising to see that many aspects of $\mathrm{T}$ cell differentiation are relatively normal in the absence of Dicer, which may reflect the longevity of mature miRNAs and/or strong counterselection against Dcr deletion. Conditional Dcr inactivation in hematopoietic stem cells and progenitors leads, however, to a dramatic phenotype, as the transplantation of Dicer-deficient bone marrow is unable to radioprotect lethally irradiated recipient mice (D. O'Carroll and A. Tarakhovsky, pers. comm.).

miRNA cloning and profiling has identified several miRNA genes that are differentially expressed during hematopoietic development (Chen et al. 2004; Monticelli et al. 2005; Table 1). For instance, miR-181a is preferentially expressed in B cells of the bone marrow and in DP thymocytes (Chen et al. 2004; Neilson et al. 2007).

Table 1. miRNA pathways in hematopoiesis

\begin{tabular}{|c|c|c|c|}
\hline miRNA & Candidate targets & Function & References \\
\hline miR-150 & $\mathrm{c}-\mathrm{Myb}$ & B cell differentiation and responses & Zhou et al. (2007); Xiao et al. (2007) \\
\hline \multirow[t]{2}{*}{ miR-155 } & c-Maf & Control of immune responses & Rodriguez et al. (2007); Thai et al. (2007) \\
\hline & & Lymphomagenesis & Costinean et al. (2006) \\
\hline $\operatorname{miR}-181 \mathrm{a}$ & Tcra, Cd69 & Lymphopoiesis & Chen et al. (2004); Neilson et al. (2007) \\
\hline miR-221, miR-222 & c-Kit & Erythropoiesis & Felli et al. (2005) \\
\hline $\operatorname{miR}-223$ & NFI-A & Granulopoiesis & Chen et al. (2004); Fazi et al. (2005) \\
\hline Gene & Cre line & Phenotype & References \\
\hline \multirow[t]{3}{*}{ Dicer } & Lck-cre (DN T cells) ${ }^{\mathrm{a}}$ & Thymocytes reduced, $\mathrm{T}_{\text {reg }}$ cells lost & Cobb et al. $(2005,2006)$ \\
\hline & Cd4-cre (DP T cells) ${ }^{\mathrm{a}}$ & Peripheral T cells decreased & Muljo et al. (2005) \\
\hline & & Autoimmune disease & Cobb et al. $(2006)$ \\
\hline Ago1 & Knock-out & No obvious hematopoietic defect & O'Carroll et al. (2007) \\
\hline \multirow[t]{2}{*}{ Ago2 } & $\mathrm{Mx}$-cre $\left(\mathrm{HSCs}^{\mathrm{b}}\right)^{\mathrm{a}}$ & $\begin{array}{l}\text { Early block of erythroid and B cell } \\
\text { development }\end{array}$ & O'Carroll et al. (2007) \\
\hline & & Reduced miRNA expression & \\
\hline Ago3 & Knock-out & No obvious hematopoietic defect & O'Carroll et al. (2007) \\
\hline
\end{tabular}
${ }^{a}$ The first developmental stage in the hematopoietic system, where deletion by the indicated Cre line is observed, is shown in
parentheses.

$\mathrm{b}$ (HSC) Hematopoietic stem cells. 
Forced retroviral expression of miR-181a in hematopoietic stem cells, followed by bone marrow transplantation, results in an increase of $B$ cells at the expense of $T$ cells in peripheral blood, suggesting that miR-181a is a positive regulator of $\mathrm{B}$ cell development (Chen et al. 2004). Alternatively, ectopic miR-181a expression may interfere with the generation or trafficking of SP T cells, given the recent identification of the 3' UTRs of the Tcra and Cd69 genes as functional miR-181a targets (Neilson et al. 2007). miR-150 is specifically expressed in mature $\mathrm{B}$ and $\mathrm{T}$ cells, and its premature expression in hematopoietic progenitors strongly impairs B cell development at the transition from the pro-B to pre-B cell stage (Zhou et al. 2007; Xiao et al. 2007). This developmental block is caused by the down-regulation of the transcription factor $\mathrm{c}-\mathrm{Myb}$, which was genetically identified as a functional miR-150 target (Xiao et al. 2007). c-Myb is required not only for early B cell development, but also for the generation of one of the mature B cell types, the so-called B1 cells (Thomas et al. 2005). Inactivation of the miR-150 gene leads to the increased generation of $\mathrm{B} 1$ cells due to enhanced c-Myb expression, whereas ectopic expression of miR-150 interferes with B1 cell development (Xiao et al. 2007). Hence, miR-150 primarily mediates its effect on B-lymphopoiesis by regulating c-Myb expression. miR-155 is processed from the noncoding RNA of the bic gene, which is highly expressed in activated macrophages, dendritic, T, and B cells as well as in a variety of human B cell lymphomas (van den Berg et al. 2003; Eis et al. 2005; Kluiver et al. 2005). Interestingly, E $\mu-m i R 155$ transgenic mice develop B cell lymphomas, further implicating miR-155 in tumorigenesis (Costinean et al. 2006). Gene disruption and conditional activation experiments revealed an important role for miR-155 in the immune system by regulating $\mathrm{T}$ helper cell differentiation and the germinal center reaction to produce an optimal $\mathrm{T}$ cell-dependent antibody response (Rodriguez et al. 2007; Thai et al. 2007). miR-155 controls these immune functions, at least in part, by regulating the expression of cytokines (Rodriguez et al. 2007; Thai et al. 2007), which is further corroborated by the identification of c-Maf, a potent transactivator of the $I 14$ gene, as a miR-155 target (Rodriguez et al. 2007). The two miRNAs miR-221 and miR-222 are down-regulated during erythroid differentiation of hematopoietic progenitors, which correlates inversely with the expression of the essential tyrosine kinase receptor c-Kit (Felli et al. 2005). Both miRNAs bind indeed to a functional target sequence in the 3' UTR of the c-kit mRNA (Felli et al. 2005). As a consequence, ectopic expression of miR-221 or miR-222 leads to reduced proliferation and accelerated maturation of differentiating erythroblasts, which is mediated, at least in part, by down-regulation of the c-Kit receptor (Felli et al. 2005). Finally, the miR-223 gene with its restricted myeloid expression pattern (Chen et al. 2004) controls granulopoiesis as part of a negative feedback loop involving the two transcription factors $\mathrm{C} / \mathrm{EBP} \alpha$ and NFI-A, which bind in a mutually exclusive manner to the same regulatory element of the miR-223 promoter (Fazi et al. 2005). During granulocyte differen- tiation, the potent activator $\mathrm{C} / \mathrm{EBP} \alpha$ is up-regulated and the negative regulator NFI-A is down-regulated, resulting in increased miR-223 expression. As miR-223 binds to the 3' UTR of NFI-A, it represses its own negative regulator, thereby maintaining its expression in granulocytes (Fazi et al. 2005). The loss of miR-223 function furthermore inhibits granulocytic differentiation, thus indicating an important role for miR-223 in granulopoiesis (Fazi et al. 2005). In summary, individual miRNAs have potent regulatory functions controlling different aspects of hematopoiesis.

\section{Essential function of Ago2 in erythroid and B cell development}

As Argonaute proteins mediate the silencing function of RISC (Peters and Meister 2007; Tolia and Joshua-Tor 2007), their inactivation provides yet another genetic approach for studying the function of miRNA pathways (Table 1). Whereas germline mutation of the Ago2 gene results in embryonic lethality (Liu et al. 2004), $\mathrm{AgO1}^{-1-}$ and $\mathrm{AgO3}^{-/-}$mice survive to adulthood without obvious developmental abnormalities and hematopoietic defects (O'Carroll et al. 2007; D. O'Carroll and A. Tarakhovsky, pers. comm.). To study the unique function of Ago 2 in hematopoiesis, O'Carroll et al. (2007) generated mice that lack Ago2 specifically in the hematopoietic system (referred to as $\mathrm{AgO}^{-/-}$mice). Using the $\mathrm{Mx}$-cre transgene, they inducibly deleted a conditional Ago2 allele in bone marrow progenitors, which were then transplanted into lethally irradiated mice to reconstitute their hematopoietic system in the absence of Ago2. These $\mathrm{Ago}^{-/-}$ mice give rise to all hematopoietic cell lineages, although the development of erythrocytes and B cells is grossly abnormal. B-lymphopoiesis is impaired at the pro-B to pre-B cell transition and at all subsequent developmental stages (O'Carroll et al. 2007). Erythropoiesis is even more severely blocked, as early basophilic erythroblasts accumulate in large numbers in the bone marrow and spleen, leading to erythroid hyperplasia and splenomegaly. In contrast, later erythroblasts and functional red blood cells are strongly reduced, causing severe anemia (O'Carroll et al. 2007). Despite its severity, the Ago2 deficiency results in a milder phenotype than similar inactivation of Dicer in blood stem cells and their progeny, which causes complete hematopoietic failure (see above). Hence, other members of the Argonaute family must fulfill important redundant functions in hematopoiesis.

Retroviral restoration of Ago2 expression in Ago2-deleted bone marrow cells prior to transplantation rescues all B-lymphoid and erythroid defects, including splenomegaly and anemia (O'Carroll et al. 2007). Surprisingly however, retroviral expression of the Slicer-deficient Ago $2^{\text {D669A }}$ protein also restores, with similar efficiency, all aspects of $\mathrm{B}$ cell and erythroid development in $\mathrm{AgO}^{-/-}$mice. Hence, the unique and defining feature of Ago2, its Slicer endonuclease activity, is dispensable for Ago2's role in hematopoiesis. Ago2 thus functions as a critical regulator of erythropoiesis and B cell develop- 
ment by mediating translational repression of so far unknown target genes. This provocative finding begs the question of whether the D669A substitution results in a catalytically dead or only severely hypomorphic Ago2 protein. The C-terminal PIWI domain of Argonaute proteins assumes an RNase $\mathrm{H}$ fold containing the characteristic triad "DDH" in the catalytic center (Tolia and Joshua-Tor 2007). D669 is the central amino acid of this triad in mammalian Ago2. All eukaryotic Ago proteins with Slicer activity contain the DDH motif in its invariant form, whereas Ago proteins with a substitution at one of the three amino acid positions lack endonuclease activity (Tolia and Joshua-Tor 2007). The Ago2 $2^{\text {D669A }}$ protein was also experimentally shown to lack endonuclease activity in both in vitro and in vivo assays (Liu et al. 2004; Rivas et al. 2005; O'Carroll et al. 2007). These arguments strongly indicate that the D669A mutation indeed eliminates the Slicer activity of Ago2. This leads to the second question of whether the catalytic engine of Ago2 is dispensable only for hematopoiesis or also for the development of the entire organism. This is a relevant question in view of the fact that only a single miRNA, miR-196, has, to date, been shown to direct Ago2-mediated slicing by binding to a perfectly complementary and evolutionarily conserved target sequence of the Hoxb8 mRNA (Mansfield et al. 2004; Yekta et al. 2004). Investigating the role of RNA slicing in mouse development will require the generation of a knock-in mouse carrying the D669A mutation in the Ago2 gene.

\section{Control of miRNA biogenesis by Argonaute proteins}

The processing of pre-miRNA and the assembly of active RISC are functionally coupled via the miRNA Loading Complex (miRLC), which is formed by the core components Dicer, Ago2, and the double-strand RNA-binding proteins TRBP and PACT /Chendrimada et al. 2005; Gregory et al. 2005; Haase et al. 2005; Maniataki and Mourelatos 2005; Lee et al. 2006). This complex binds and processes pre-miRNA to create a transient miRNA duplex. RNA unwinding or Ago2 slicing subsequently removes the passenger strand to generate the active RISC consisting of the guide strand and Ago2 (Matranga et al. 2005; Leuschner et al. 2006; Fig. 1). While the Ago2containing miRLC has been extensively studied, other members of the Argonaute family must be similarly assembled into active RISC, as they are also found in vivo in complexes with Dicer (Meister et al. 2005) and bind the same broad spectrum of miRNAs in RISC (Liu et al. 2004; Meister et al. 2004). However, it remained unclear whether the Argonaute protein contributes to the premiRNA processing activity of the miRLC complex. By microarray comparison of control and $\mathrm{AgO}^{-/-}$cells, O'Carroll et al. (2007) have now demonstrated that the loss of Ago2 results in a global reduction of mature miRNAs in erythroblasts, fibroblasts, and hepatocytes. Instead, pre-miRNAs accumulate as shown in $\mathrm{AgO}^{-/-}$ fibroblasts, which uncovers a critical function of Ago2 in miRNA biogenesis. Rescue experiments ruled out a role for the catalytic activity of Ago2 in pre-miRNA process-

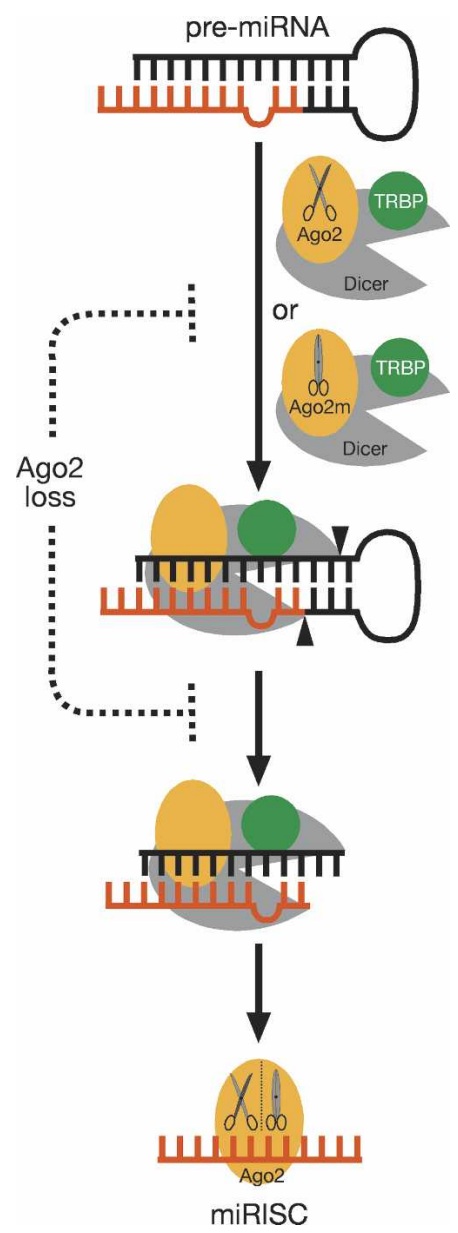

Figure 1. Possible functions of Ago2 in pre-miRNA processing. A schematic diagram of miRNA biogenesis is shown. The guide RNA strand of active RISC is indicated in red, while the complementary passenger strand of the transient miRNA duplex is shown in black. Arrowheads indicate the positions where Dicer cleaves the pre-miRNA molecule. The loss of Ago2 may interfere with one of the two pre-miRNA processing steps indicated by the dashed lines. Closed scissors symbolize the absence of Slicer endonuclease activity in the Ago2 ${ }^{\mathrm{D} 669 \mathrm{~A}}$ protein (Ago2m).

ing in vivo (O'Carroll et al. 2007) consistent with the finding that Dicer in a complex with the Slicer-inactive Ago2 ${ }^{\text {D669A }}$ protein has normal endonuclease activity in vitro (Maniataki and Mourelatos 2005). Ago2 deficiency reduces but does not eliminate miRNA production (O'Carroll et al. 2007), and hence the residual premiRNA processing activity is likely contributed by Agol and Ago3, which are coexpressed with Ago2 in mouse fibroblasts (Liu et al. 2004). The expression of miRNAs is, however, normal in $\mathrm{AgO1}^{-/-}$and $\mathrm{AgO3}^{-/-}$fibroblasts, indicating that Ago2 is the dominant Argonaute family member participating in pre-miRNA processing in this cell type (O'Carroll et al. 2007). Ago2 could potentially control two different steps of miRNA biogenesis (Fig. 1). Ago2 may be required in vivo for the assembly and/or stabilization of the miRLC complex or for regulating Dicer's endonuclease activity in the complex. Prior to 
the study of $\mathrm{O}^{\prime}$ Carroll et al. (2007), Ago2 was considered to be a unique member of the Argonaute family due to its Slicer endonulease activity. Now we know that the Slicer activity makes only a minor contribution to the biological function of Ago2. Instead, Ago2 is a unique family member because of its nonredundant role in development and miRNA biogenesis, which will warrant future studies of this important member of the RNA silencing machinery.

\section{Acknowledgments}

We thank A. Tarakhovsky and K. Rajewsky for communicating results prior to publication, and A. Tarakhovsky for comments on the manuscript.

\section{References}

Aravin, A., Gaidatzis, D., Pfeffer, S., Lagos-Quintana, M., Landgraf, P., Iovino, N., Morris, P., Brownstein, M.J., KuramochiMiyagawa, S., Nakano, T., et al. 2006. A novel class of small RNAs bind to MILI protein in mouse testes. Nature 442: 203-207.

Bernstein, E., Caudy, A.A., Hammond, S.M., and Hannon, G.J. 2001. Role for a bidentate ribonuclease in the initiation step of RNA interference. Nature 409: 363-366.

Bernstein, E., Kim, S.Y., Carmell, M.A., Murchison, E.P., Alcorn, H., Li, M.Z., Mills, A.A., Elledge, S.J., Anderson, K.V., and Hannon, G.J. 2003. Dicer is essential for mouse development. Nat. Genet. 35: 215-217.

Chen, C.-Z., Li, L., Lodish, H.F., and Bartel, D.P. 2004. MicroRNAs modulate hematopoietic lineage differentiation. Science 303: 83-86.

Chendrimada, T.P., Gregory, R.I., Kumaraswamy, E., Norman, J., Cooch, N., Nishikura, K., and Shiekhattar, R. 2005. TRBP recruits the Dicer complex to Ago 2 for microRNA processing and gene silencing. Nature 436: 740-744.

Cobb, B.S., Nesterova, T.B., Thompson, E., Hertweck, A., O'Connor, E., Godwin, J., Wilson, C.B., Brockdorff, N., Fisher, A.G., Smale, S.T., et al. 2005. T cell lineage choice and differentiation in the absence of the RNase III enzyme Dicer. J. Exp. Med. 201: 1367-1373.

Cobb, B.S., Hertweck, A., Smith, J., O'Connor, E., Graf, D., Cook, T., Smale, S.T., Sakaguchi, S., Livesey, F.J., Fisher, A.G., et al. 2006. A role for Dicer in immune regulation. J. Exp. Med. 203: 2519-2527.

Costinean, S., Zanesi, N., Pekarsky, Y., Tili, E., Volinia, S., Heerema, N., and Croce, C.M. 2006. Pre-B cell proliferation and lymphoblastic leukemia/high-grade lymphoma in E $\mathrm{\mu}-$ miR155 transgenic mice. Proc. Natl. Acad. Sci. 103: 70247029.

Eis, P.S., Tam, W., Sun, L., Chadburn, A., Li, Z., Gomez, M.F., Lund, E., and Dahlberg, J.E. 2005. Accumulation of miR-155 and BIC RNA in human B cell lymphomas. Proc. Natl. Acad. Sci. 102: 3627-3632.

Fazi, F., Rosa, A., Fatica, A., Gelmetti, V., De Marchis, M.L., Nervi, C., and Bozzoni, I. 2005. A minicircuitry comprised of microRNA-223 and transcription factors NFI-A and C/EBP $\alpha$ regulates human granulopoiesis. Cell 123: 819-831.

Felli, N., Fontana, L., Pelosi, E., Botta, R., Bonci, D., Facchiano, F., Liuzzi, F., Lulli, V., Morsilli, O., Santoro, S., et al. 2005. MicroRNAs 221 and 222 inhibit normal erythropoiesis and erythroleukemic cell growth via kit receptor down-modulation. Proc. Natl. Acad. Sci. 102: 18081-18086.
Gregory, R.I., Chendrimada, T.P., Cooch, N., and Shiekhattar, R. 2005. Human RISC couples microRNA biogenesis and posttranscriptional gene silencing. Cell 123: 631-640.

Haase, A.D., Jaskiewicz, L., Zhang, H., Laine, S., Sack, R., Gatignol, A., and Filipowicz, W. 2005. TRBP, a regulator of cellular PKR and HIV-1 virus expression, interacts with Dicer and functions in RNA silencing. EMBO Rep. 6: 961967.

Hutvágner, G., McLachlan, J., Pasquinelli, A.E., Bálint, É., Tuschl, T., and Zamore, P.D. 2001. A cellular function for the RNA-interference enzyme Dicer in the maturation of the let-7 small temporal RNA. Science 293: 834-838.

Kiriakidou, M., Tan, G.S., Lamprinaki, S., De Planell-Saguer, M., Nelson, P.T., and Mourelatos, Z. 2007. An mRNA m ${ }^{7}$ cap binding-like motif within human Ago2 represses translation. Cell 129: 1141-1151.

Kloosterman, W.P. and Plasterk, R.H. 2006. The diverse functions of microRNAs in animal development and disease. Dev. Cell 11: 441-450.

Kluiver, J., Poppema, S., de Jong, D., Blokzijl, T., Harms, G., Jacobs, S., Kroesen, B.J., and van den Berg, A. 2005. BIC and miR-155 are highly expressed in Hodgkin, primary mediastinal and diffuse large B cell lymphomas. J. Pathol. 207: 243 249 .

Lagos-Quintana, M., Rauhut, R., Lendeckel, W., and Tuschl, T. 2001. Identification of novel genes coding for small expressed RNAs. Science 294: 853-858.

Lau, N.C., Lim, L.P., Weinstein, E.G., and Bartel, D.P. 2001. An abundant class of tiny RNAs with probable regulatory roles in Caenorhabditis elegans. Science 294: 858-862.

Lee, R.C. and Ambros, V. 2001. An extensive class of small RNAs in Caenorhabditis elegans. Science 294: 862-864.

Lee, R.C., Feinbaum, R.L., and Ambros, V. 1993. The C. elegans heterochronic gene lin-4 encodes small RNAs with antisense complementarity to lin-14. Cell 75: 843-854.

Lee, Y., Ahn, C., Han, J., Choi, H., Kim, J., Yim, J., Lee, J., Provost, P., Radmark, O., Kim, S., et al. 2003. The nuclear RNase III Drosha initiates microRNA processing. Nature 425: 415-419.

Lee, Y., Hur, I., Park, S.Y., Kim, Y.-K., Suh, M.R., and Kim, V.N. 2006. The role of PACT in the RNA silencing pathway. EMBO J. 25: 522-532.

Leuschner, P.J., Ameres, S.L., Küng, S., and Martinez, J. 2006. Cleavage of the siRNA passenger strand during RISC assembly in human cells. EMBO Rep. 7: 314-320.

Lim, L.P., Lau, N.C., Garrett-Engele, P., Grimson, A., Schelter, J.M., Castle, J., Bartel, D.P., Linsley, P.S., and Johnson, J.M. 2005. Microarray analysis shows that some microRNAs downregulate large numbers of target mRNAs. Nature 433: 769-773.

Liu, J., Carmell, M.A., Rivas, F.V., Marsden, C.G., Thomson, J.M., Song, J.-J., Hammond, S.M., Joshua-Tor, L., and Hannon, G.J. 2004. Argonaute2 is the catalytic engine of mammalian RNAi. Science 305: 1437-1441.

Maniataki, E. and Mourelatos, Z. 2005. A human, ATP-independent, RISC assembly machine fueled by pre-miRNA. Genes \& Dev. 19: 2979-2990.

Mansfield, J.H., Harfe, B.D., Nissen, R., Obenauer, J., Srineel, J., Chaudhuri, A., Farzan-Kashani, R., Zuker, M., Pasquinelli, A.E., Ruvkun, G., et al. 2004. MicroRNA-responsive "sensor" transgenes uncover Hox-like and other developmentally regulated patterns of vertebrate microRNA expression. Nat. Genet. 36: 1079-1083.

Martinez, J. and Tuschl, T. 2004. RISC is a 5' phosphomonoester-producing RNA endonuclease. Genes \& Dev. 18: 975980. 
Matranga, C., Tomari, Y., Shin, C., Bartel, D.P., and Zamore, P.D. 2005. Passenger-strand cleavage facilitates assembly of siRNA into Ago2-containing RNAi enzyme complexes. Cell 123: 607-620.

Meister, G., Landthaler, M., Patkaniowska, A., Dorsett, Y., Teng, G., and Tuschl, T. 2004. Human Argonaute2 mediates RNA cleavage targeted by miRNAs and siRNAs. Mol. Cell 15: 185-197.

Meister, G., Landthaler, M., Peters, L., Chen, P.Y., Urlaub, H., Luhrmann, R., and Tuschl, T. 2005. Identification of novel Argonaute-associated proteins. Curr. Biol. 15: 2149-2155.

Monticelli, S., Ansel, K.M., Xiao, C., Socci, N.D., Krichevsky, A.M., Thai, T.-H., Rajewsky, N., Marks, D.S., Sander, C., Rajewsky, K., et al. 2005. MicroRNA profiling of the murine hematopoietic system. Genome Biol. 6: R71. doi: 10.1186/ gb-2005-6-8-r71

Muljo, S.A., Ansel, K.M., Kanellopoulou, C., Livingston, D.M., Rao, A., and Rajewsky, K. 2005. Aberrant T cell differentiation in the absence of Dicer. J. Exp. Med. 202: 261-269.

Neilson, J.R., Zheng, G.X.Y., Burge, C.B., and Sharp, P.A. 2007. Dynamic regulation of miRNA expression in ordered stages of cellular development. Genes \& Dev. 21: 578-589.

O'Carroll, D., Mecklenbrauker, I., Das, P.P., Santana, A., Koenig, U., Enright, A.J., Miska, E.A., and Tarakhovsky, A. 2007. A Slicer-independent role for Argonaute 2 in hematopoiesis and the microRNA pathway. Genes \& Dev. (this issue) doi: $10.1101 /$ gad.1565607.

Peters, L. and Meister, G. 2007. Argonaute proteins: Mediators of RNA silencing. Mol. Cell 26: 611-623.

Pillai, R.S., Bhattacharyya, S.N., and Filipowicz, W. 2007. Repression of protein synthesis by miRNAs: How many mechanisms? Trends Cell Biol. 17: 118-126.

Rivas, F.V., Tolia, N.H., Song, J.J., Aragon, J.P., Liu, J., Hannon, G.J., and Joshua-Tor, L. 2005. Purified Argonaute2 and an siRNA form recombinant human RISC. Nat. Struct. Mol. Biol. 12: 340-349.

Rodriguez, A., Vigorito, E., Clare, S., Warren, M.V., Couttet, P., Soond, D.R., van Dongen, S., Grocock, R.J., Das, P.P., Miska, E.A., et al. 2007. Requirement of bic/microRNA-155 for normal immune function. Science 316: 608-611.

Ruby, J.G., Jan, C.H., and Bartel, D.P. 2007. Intronic microRNA precursors that bypass Drosha processing. Nature 448: 8386.

Schwarz, D.S., Tomari, Y., and Zamore, P.D. 2004. The RNAinduced silencing complex is a $\mathrm{Mg}^{+}$-dependent endonuclease. Curr. Biol. 14: 787-791.

Seto, A.G., Kingston, R.E., and Lau, N.C. 2007. The coming of age for piwi proteins. Mol. Cell 26: 603-609.

Thai, T.-H., Calado, D.P., Casola, S., Ansel, K.M., Xiao, C., Xue, Y., Murphy, A., Frendewey, D., Valenzuela, D., Kutok, J.L., et al. 2007. Regulation of the germinal center response by microRNA-155. Science 316: 604-608.

Thomas, M.D., Kremer, C.S., Ravichandran, K.S., Rajewsky, K., and Bender, T.P. 2005. c-Myb is critical for B cell development and maintenance of follicular B cells. Immunity 23: $275-286$.

Tolia, N.H. and Joshua-Tor, L. 2007. Slicer and the Argonautes. Nat. Chem. Biol. 3: 36-43.

van den Berg, A., Kroesen, B.J., Kooistra, K., de Jong, D., Briggs, J., Blokzijl, T., Jacobs, S., Kluiver, J., Diepstra, A., Maggio, E., et al. 2003. High expression of B-cell receptor inducible gene $B I C$ in all subtypes of Hodgkin lymphoma. Genes Chromosomes Cancer 37: 20-28.

Wightman, B., Ha, I., and Ruvkun, G. 1993. Posttranscriptional regulation of the heterochronic gene lin-14 by lin- 4 mediates temporal pattern formation in C. elegans. Cell 75: 855-862.
Xiao, C., Calado, D.P., Galler, G., Thai, T.-H., Patterson, H.D., Wang, J., Rajewsky, N., Bender, T.P., and Rajewsky, K. 2007. miR-150 control B cell differentiation by targeting the transcription factor c-Myb. Cell (in press).

Yang, W.J., Yang, D.D., Na, S., Sandusky, G.E., Zhang, Q., and Zhao, G. 2005. Dicer is required for embryonic angiogenesis during mouse development. J. Biol. Chem. 280: 9330-9335.

Yekta, S., Shih, I.-H., and Bartel, D.P. 2004. MicroRNA-directed cleavage of HOXB8 mRNA. Science 304: 594-596.

Yi, R., Qin, Y., Macara, I.G., and Cullen, B.R. 2003. Exportin-5 mediates the nuclear export of pre-microRNAs and short hairpin RNAs. Genes \& Dev. 17: 3011-3016.

Zheng, Y. and Rudensky, A.Y. 2007. Foxp3 in control of the regulatory T cell lineage. Nat. Immunol. 8: 457-462.

Zhou, B., Wang, S., Mayr, C., Bartel, D.P., and Lodish, H.F. 2007. miR-150, a microRNA expressed in mature B and T cells, blocks early B cell development when expressed prematurely. Proc. Nat1. Acad. Sci. 104: 7080-7085. 


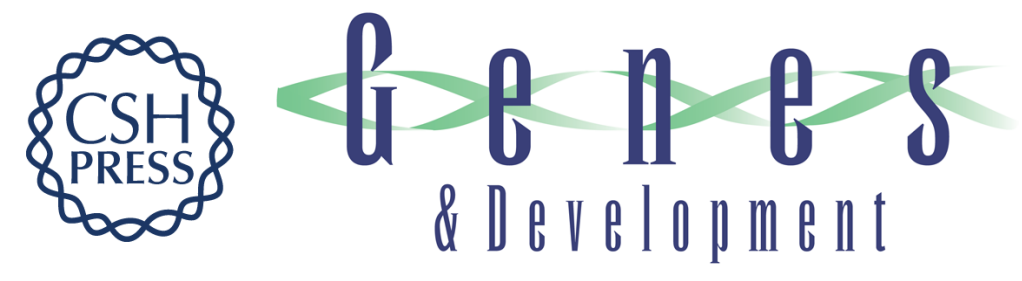

\section{Life beyond cleavage: the case of Ago2 and hematopoiesis}

Javier Martinez and Meinrad Busslinger

Genes Dev. 2007, 21:

Access the most recent version at doi:10.1101/gad.1591407

Related Content

References

\section{License}

Email Alerting

Service
This article cites 53 articles, 24 of which can be accessed free at: http://genesdev.cshlp.org/content/21/16/1983.full.html\#ref-list-1

Articles cited in:

http://genesdev.cshlp.org/content/21/16/1983.full.html\#related-urls

A Slicer-independent role for Argonaute 2 in hematopoiesis and the microRNA pathway

Dónal O'Carroll, Ingrid Mecklenbrauker, Partha Pratim Das, et al.

Genes Dev. August , 2007 21: 1999-2004

Receive free email alerts when new articles cite this article - sign up in the box at the top right corner of the article or click here.

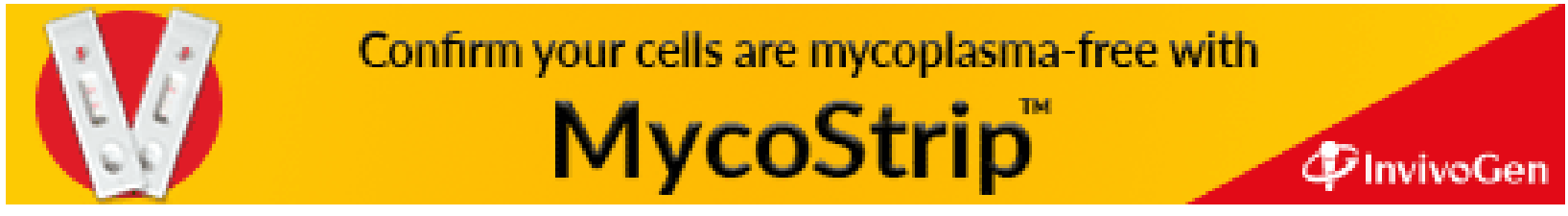

